\title{
PEMBUATAN ROTI TAWAR SUBTITUSI TEPUNG UBI UNGU
}

\author{
Tri Marta Fadhilah ${ }^{1^{*}}$ \\ 1. Program Studi S1 Ilmu Gizi, STIKes Mitra Keluarga, Bekasi-Indonesia \\ *Korespondensi: Tri Marta Fadhilah | STIKes Mitra Keluarga | martafadhilah88@ gmail.com
}

\begin{abstract}
Abstrak
Pendahuluan: Roti Tawar merupakan roti yang terbuat dari adonan tepung terigu tanpa menggunakan telur dengan gula sedikit. Pemanfaatan bahan lokal ubi ungu pada pembuatan roti tawar bertujuan untuk mengetahui perbedaan kualitas, tingkat kesukaan dan mengetahui kandungan antosianin.

Metode: Desain eksperimen yang digunakan desain acak sempurna dengan teknik pengambilan sampel menggunakan simple random sampling. Pengumpulan data dilakukan dengan metode penilaian subjektif dan objektif. Analisisi deskriptif prosentasi digunukan untuk menganalisis kesukaan dari roti tawar subtitusi tepung ubi ungu.

Hasil: Roti tawar yang dihasilkan terdapat adanya perbedaan kualitas yang ditinjau dari aspek warna (dalam dan luar), aroma, rasa dan tekstur. Hasil yang banyak disukai yaitu roti tawar subtitusi tepung ubi ungu $10 \%$. Kandungan zat anthosianin dan serat paling tinggi terdapat pada roti tawar subtitusi tepung ubi ungu 30\% yaitu 235,89 mg zat
\end{abstract} anthosianin dan $2,34 \%$ serat.

Kesimpulan: Kesimpulan bahwa semakin banyak pemberian tepung ubi ungu pada pembuatan roti tawar maka akan mempengaruhi kualitas hasil roti tawar dan semakin tinggi kandungan zat antosianin dan serat pada roti tawar.

Kata Kunci : Pembuatan Roti Tawar, Subtitusi Tepung Ubi Ungu.

Diterima 23 Oktober 2018; Accepted 30 Desember 2018

\section{PENDAHULUAN}

Roti tawar merupakan roti yang terbuat dari adonan tanpa menggunakan telur dengan sedikit gula atau tidak sama sekali, penggunaan gula pada pembuatan roti tawar hanya digunakan dalam percepatan proses fermentasi (Lilik Noer Yulianti, 2004). Harga yang relative murah, menyebabkan roti rawar mudah dijangkau bagi seluruh lapisan masyarakat. Roti tawar memiliki tekstur yang halus seperti kapas, ringan dan rasanya tawar.

Bahan dasar/bahan pokok pembuatan roti tawar sebagian besar adalah tepung terigu yang masih import. Tingginya konsumsi roti tawar baik sebagai sarapan pagi, maupun sebagai snack atau camilan, menyebabkan kebutuhan tepung terigu sebagai bahan utama pembuat roti ikut meningkat (Bayu, 2008:1). Berdasarkan data yang telah dilakukan oleh badan statistic nasional, di Indonesia jumlah impor gandum mencapai 6,3 juta ton pertahun yang sebelumnya di tahun 2011 nilai impor gandum sebesar 5,4 juta ton (El Hida, 2013).

Di Indonesia ubi jalar kurang banyak dimanfaatkan dengan baik oleh masyarakat ketika masa musim panen. Pengolahan ubi jalar pada umumnya hanya direbus, dikukus atau digoreng saja untuk dimakan. Kelemahan ubi jalar adalah cepat busuk jika dalam keadaan segar, ubi jalar ungu hanya memiliki masa simpan 5 bulan (Sarwono, 2005). Oleh karena itu untuk meningkatkan nilai ekonomi dari ubi jalar tersebut maka diolah menjadi tepung ubi jalar. Dengan diolah menjadi tepung, ubi jalar memiliki beberapa keuntungan yaitu tahan lama, meningkatkan nilai jual dan praktis dalam penggunaan pembuatan makanan misalnya roti tawar dan lainnya.

Ubi jalar ungu memiliki kaya akan kandungan gizi seperti Vitamin B1, B2, C dan E), mineral (Ca, Mg, $\mathrm{K}$ dan $\mathrm{Zn}$ ), serat dan karbohidrat. Bagian kulit dan daging ubi jalar ungu memiliki warna ungu yang cukup pekat disebabkan karena terdapat pigmen ungu antosianin (Santo dan Estiasih, 2014). Anthosianin yang cukup tinggi dibandingkan dengan ubi jalar yang lain yaitu $110,51 \mathrm{mg} / 100 \mathrm{~g}$ yang berfungsi sebagai anti kanker, anti bakteri perlindungan terhadap kerusakan hati, penyakit jantung dan stroke (Sarwono, 2005). Kumalaningsih (2006) menyebutkan bahwa kandungan antosianin pada ubi jalar ungu mencapai $519 \mathrm{mg} / 100 \mathrm{~g}$ berat basah, sedangkan menurut Astawan dan Widowati (2005) menyatakan bahwa kandungan antosianin ubi jalar ungu berkisar antara 51,5 sampai $174,7 \mathrm{mg} / 100 \mathrm{~g}$. Kandungan antosianin yang tinggi pada ubi jalar ungu berfungsi sebagai antimutageik dan antidiabetes (Terahara et al.,2004),memiliki aktivitas antikarsinogenik (Katsube et al.,2003), serta sebagai antioksidan (Jawi dan Budiasa, 2011). 
Dalam pembuatan roti tawar pada dasarnya bahan utama yang digunakan adalah tepung terigu yang memiliki kandungan pati, karbohidrat sebagai sumber energi dan memiliki kandungan protein yang tinggi yaitu 11\% - 13\% (Bogasari Baking Center, 2006). Pada tepung ubi jalar ungu juga memiliki karakteristik yang hampir sama dengan tepung terigu yaitu memiliki kandungan pati, karbohidrat sebagai sumber energi dan memiliki protein, akan tetapi pada tepung ubi jalar ungu memiliki protein yang lebih rendah dari tepung terigu sehingga tepung ubi jalar ungu tidak dapat dijadikan bahan utama dalam pembuatan roti tawar melainkan hanya dapat dijadikan bahan pengganti sebagian kecil saja atau bahan subtitusi dari tepung terigu.

Berdasarkan uraian tersebut maka pemanfaatan ubi jalar ungu yang dijadikan tepung pada pembuatan roti tawar diharapkan mengurangi ketergantungan terhadap tegung terigu. Selain itu dapat menambah variasi roti tawar dipasaran dan dapat menambah nilai gizi yang lebih yang bermanfaat untuk kesehatan karena menggunakan tepung ubi jalar ungu. Percobaan pembuatan roti tawar yang akan dilakukan dengan subtitusi tepung ubi jalar ungu yang berbeda yaitu : 30\%, 20\% dan 10\% sehingga hasil eksperimen akan dapat dilihat dari aspek tekstur, warna, rasa dan aroma.

\section{METODE}

Populasi pada penelitian ini adalah roti tawar subtitusi tepung ubi jalar ungu sebesar $30 \%, 20 \%$ dan $10 \%$, sedangkan sampel pada penelitian adalah sebagian dari roti tawar subtitusi tepung ubi jalar ungu sebanyak 30\%, 20\% dan 10\%. Teknik pengambilan sampel yang digunakan pada penelitian ini adalah simple random sampling (secara acak). Kualitas roti tawar subtitusi tepung ubi jalar ungu dengn indicator warna, rasa, aroma dan tekstur, dan kandungan zat anthosianin serta serat kasar merupakan variable terikat. Jumlah bahan, ukuran bahan, alat yang digunakan, proses pembuatan, suhu pembakaran dan waktu pengovenan merupakan variable kontrol.

\section{HASIL}

Berdasarkan uji inderawi diperoleh hasil berikut ini

\section{a. Warna dalam}

Rerata skor menunjukkan bahwa rerata skor tertinggi berdasarkan indikator warna dalam adalah pada sampel A yaitu roti tawar dengan subtitusi tepung ubi jalar ungu 30\% dengan rerata skor sebesar 3,73, maka sampel A adalah sampel terbaik. Untuk mempermudah dan memperjelas perbedaan warna dalam pada roti tawar dapat dilihat pada gambar diagram berikut ini.

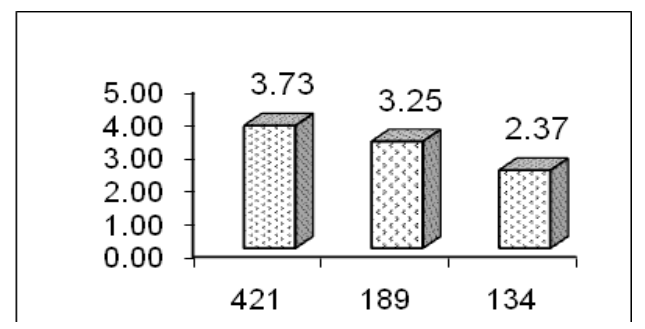

Gambar 1. Diagram rerata (mean) aspek warna dalam

\section{b. Warna Luar}

Rerata skor menunjukkan bahwa rerata skor tertinggi berdasarkan indikator warna luar adalah pada sampel C yaitu roti tawar dengan subtitusi tepung ubi jalar ungu 10\% dengan rerata skor sebesar 3,67, maka sampel $\mathrm{C}$ adalah sampel terbaik. Untuk mempermudah dan memperjelas perbedaan warna dalam pada roti tawar dapat dilihat pada diagram dibawah ini: 


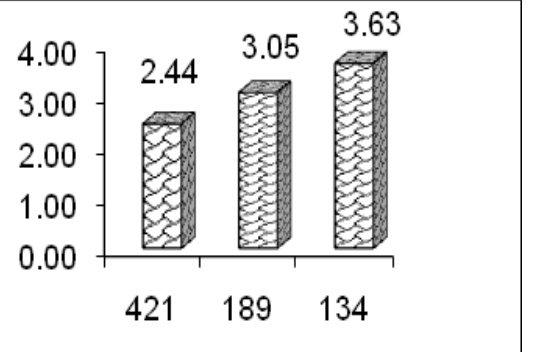

Gambar 2. Diagram rerata (mean) aspek warna luar

\section{c. Rasa}

Rerata skor menunjukkan bahwa rerata skor tertinggi berdasarkan indikator rasa adalah pada sampel C yaitu roti tawar dengan subtitusi tepung ubi jalar ungu 10\% dengan rerata skor sebesar 3,76, maka sampel $\mathrm{C}$ adalah sampel terbaik. Untuk mempermudah dan memperjelas perbedaan warna dalam pada roti tawar dapat dilihat pada gambar 3 .

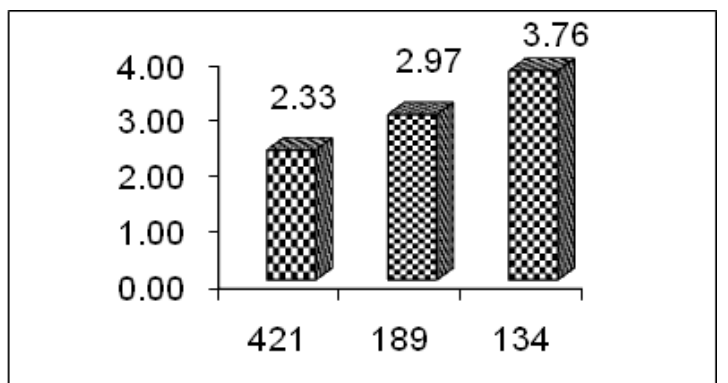

Gambar 3. Diagram rerata (mean) aspek rasa

\section{d. Aroma}

Rerata skor menunjukkan bahwa rerata skor tertinggi berdasarkan indikator aroma adalah pada sampel A yaitu roti tawar dengan subtitusi tepung ubi jalar ungu 30\% dengan rerata skor sebesar 3,65, maka sampel A adalah sampel terbaik. Untuk mempermudah dan memperjelas perbedaan warna dalam pada roti tawar dapat dilihat pada gambar diagram berikut ini.

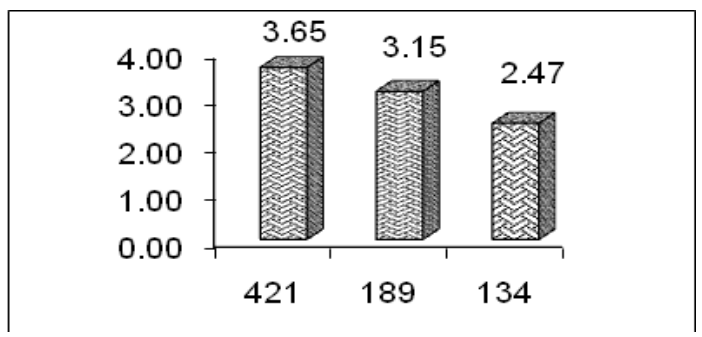

Gambar 4. Diagram rerata (mean) aspek aroma

\section{e. Tekstur}

Rerata skor menunjukkan bahwa rerata skor tertinggi berdasarkan indikator tekstur adalah pada sampel $\mathrm{C}$ yaitu roti tawar dengan subtitusi tepung ubi jalar ungu $10 \%$ dengan rerata skor sebesar 3,64, maka sampel $\mathrm{C}$ adalah sampel terbaik. Untuk mempermudah dan memperjelas perbedaan warna dalam pada roti tawar dapat dilihat pada gambar diagram berikut ini. 


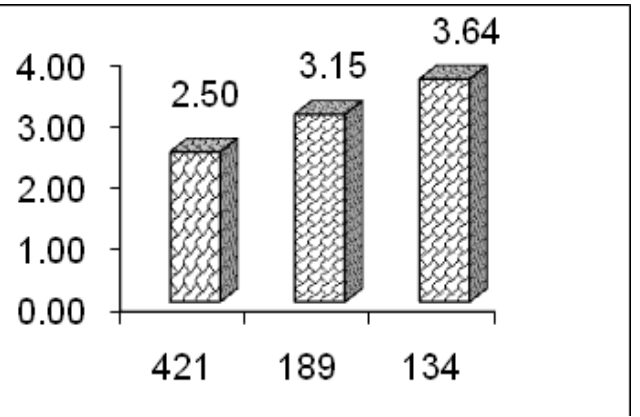

Gambar 5.Diagram rerata (mean) aspek tekstur

\section{Hasil Uji Kesukaan}

Uji kesukaan dilakukan untuk mengetahui minat masyarakat terhadap roti tawar dengan subtitusi tepung ubi jalar ungu hasil eksperimen. Berdasarkan hasil pengujian dari 80 orang panelis tidak terlatih dapat dilihat pada tabel halaman berikut ini.

Tabel 1. Ringkasan hasil uji kesukaan roti tawardengan subtitusi tepung ubi jalar ungu.

\begin{tabular}{|c|c|c|c|}
\hline \multirow{2}{*}{ Indikator } & \multicolumn{3}{|c|}{ Nilai } \\
\cline { 2 - 4 } & A & B & C \\
\hline Warna & 76 & 83 & 81 \\
\hline Rasa & 77 & 78 & 85 \\
\hline Aroma & 76 & 80 & 83 \\
\hline Tekstur & 78 & 79 & 83 \\
\hline
\end{tabular}

Keterangan: Nilai $70-79$ suka

Nilai 80 - 90 sangat suka

\section{Hasil Uji Laboratorium}

Uji laboratorium dilakukan untuk mengetahui kandungan zat anthosianin dan serat kasar didalam roti tawar dengan subtitusi tepung ubi jalar ungu. Berikut hasil uji laboratorium yang dilakukan di Laboratorium Pertanian Universitas Semarang.

Tabel 2. Hasil Uji antosianin

\begin{tabular}{|c|c|c|}
\hline No. & Sampel & Kadar Zat Anthosianin (mg) \\
\hline 1 & A. (tepung ubi jalar ungu 30\% terigu 70\%) & 235,89 \\
\hline 2 & B. (tepung ubi jalar ungu 20\% terigu 80\%) & 150,47 \\
\hline 3 & C. (Tepung ubi jalar ungu 10\% terigu 90\%) & 76,34 \\
\hline
\end{tabular}

Tabel 3. Hasil uji kadar serat kasar substitusi ubi

\begin{tabular}{|c|c|c|}
\hline No. & \multicolumn{1}{|c|}{ Sampel } & $\begin{array}{c}\text { Kadar Serat Kasar } \\
(\mathbf{\%})\end{array}$ \\
\hline 1 & A. (tepung ubi jalar ungu 30\% terigu 70\%) & 2,34 \\
\hline 2 & B. (tepung ubi jalar ungu 20\% terigu 80\%) & 1,97 \\
\hline 3 & C. (Tepung ubi jalar ungu 10\% terigu 90\%) & 1,25 \\
\hline
\end{tabular}

\section{PEMBAHASAN}

\section{Kualitas Warna Dalam}

Berdasarkan hasil analisis yang dilakukan oleh 25 orang panelis menunjukkan bahwa kriteria warna dalam roti tawar yang baik adalah roti tawar subtitusi tepung ubi jalar ungu sebanyak $30 \%$ dengan kriteria warna ungu kecoklatan. Sedangkan untuk sampel yang kurang baik adalah sampel roti tawar subtitusi tepung ubi jalar ungu sebanyak $10 \%$ dengan kriteria warna ungu keputihan.

Dengan demikian perbedaan jumlah tepung ubi jalar ungu dengan tepung terigu berpengaruh terhadap 
warna pada bagian dalam roti tawar. Adanya perbedaan warna pada roti tawar khususnya pada warna bagian dalam, hal ini dikarenakan perbedaan prosentase penggunaan tepung terigu dan tepung ubi jalar ungu.

Perbedaan jumlah tersebut menyebabkan perbedaan kandungan protein yang berasal dari tepung terigu dan karbohidrat dari tepung ubi jalar ungu yang mengalami reaksi maillard. Menurut Winarno (2002), reaksi maillard merupakan reaksi antara karbohidrat, khususnya gula pereduksi dengan $\mathrm{NH}_{2}$ dari protein yang menghasilkan senyawa hidroksimetilfurfural yang kemudian berlanjut menjadi furfural. Furfural yang terbentuk kemudian berpolimer membentuk senyawa melanoidin yang berwarna coklat. Melanoidin inilah yang memberikan warna coklat pada roti tawar yang dihasilkan.

Menurut Nunung (2005), semakin tinggi protein yang ditambahkan menyebabkan melanoidin yang dihasilkan memberikan intensitas warna yang kurang, sehingga warna produk yang dihasilkan menjadi ungu kecoklatan. Hal ini terlihat perbedaan pada sampel yang menggunakan 90\% tepung terigu lebih putih dari pada sampel yang menggunakan tepung terigu $80 \%$.

\section{Kualitas Warna Luar}

Tingkatan Kriteria warna bagian luar roti tawar hasil eksperimen dari yang terbaik adalah kuning kecoklatan, coklat muda, coklat dan coklat tua. Berdasarkan hasil analisis yang dilakukan oleh 25 penelis diketahui bahwa sampel roti tawar subtitusi tepung ubi jalar ungu sebanyak 10\% merupakan sampel yang terbaik, sedangkan sampel roti tawar subtitusi ubi jalar ungu sebanyak 30\% merupakan sampel yang kurang baik karena pada sampel tersebut warna bagian luar yang dihasilkan berwarna coklat tua.

Perbedaan warna pada bagian luar roti tawar dikarenakan kandungan gula yang terkandung pada tepung ubi jalar ungu yang cukup tinggi Maka formula 30\% : 70\% (tepung ubi jalar ungu : tepung terigu ) warna pada bagian luar roti tawar yang dihasilkan berwarna coklat tua, sedangkan untuk formula $10 \%$ : 90\% (tepung ubi jalar ungu : tepung terigu ) menghasilkan warna bagian luar kuning kecoklatan, hal ini dikarenakan jumlah kandungan gula pada adonan yang cukup tinggi. Selain itu perbedaan warna bagian luar pada roti tawar juga bisa diakibatkan terjadinya reaksi maillard yang terjadi pada adonan karena perbedaan jumlah karbohidrat dan protein yang berbeda (Winarno, 2002). Menurut Sangkan Paran (2009), fungsi gula pada pembuatan roti tawar adalah sebagai pemberi rasa, aroma dan membentuk warna pada kulit roti tawar sehingga jumlah subtitusi sangat berpengaruh pada warna. Adanya kandungan gula pada tepung ubi jalar ungu dan gula pada adonan membuat kandungan gula pada adonan menjadi tinggi sehingga pada saat adonan dioven maka akan terjadi proses karamelisasi pada adonan dan menimbulkan reaksi browning (munculnya warna coklat) pada bagian luar roti tawar. Selain itu pada permukaan roti tawar menjadi basah dibanding dengan sampel yang lain. Hal ini dikarenakan kadar air pada roti meningkat seiring proses fermentasi yang berjalan pada saat pembuatan roti.

\section{Kualitas Rasa}

Berdasarkan hasil penilaian oleh 25 orang panelis menunjukkan adanya perbedaan rasa yang dihasilkan pada roti tawar hasil eksperimen. Menurut panelis sampel roti tawar subtitusi tepung ubi jalar sebanyak $10 \%$ merupakan sampel terbaik, sedangkan untuk sampel roti tawar subtitusi tepung ubi jalar ungu sebanyak $30 \%$ merupakan sampel yang kurang baik.

Dari hasil analisis menunjukkan bahwa perbedaan prosentase penggunaan tepung ubi jalar ungu dan tepung terigu pada pembuatan roti tawar ini berpengaruh terhadap rasa pada roti tawar yang dihasilkan. Hal ini karena pada tepung baik ubi jalar ungu maupun tepung terigu mempunyai kandungan karbohidrat, lemak, dan protein yang berbeda-beda. Karbohidrat berperan dalam menentukan karakteristik bahan makanan misalnya rasa, warna dan tekstur. Lemak berperan dalam memberi flavor tertentu pada bahan pangan. Protein berfungsi mengendalikan tekstur, penampilan dan flavor pangan (Sangkan Paran (2009).

Perbedaan jumlah tepung ubi jalar ungu dan tepung terigu menyebabkan perbedaan kandungan karbohidrat pada masing-masing sampel. Didalam karbohidrat terdapat glukosa, sukrosa dan pati yang dapat meningkatkan citarasa pada bahan makanan (Winarno, 2002). Misalnya sukrosa menimbulkan rasa manis, sementara itu pati menimbulkan rasa yang khas pada makanan.

Semakin banyak prosentase tepung ubi jalar ungu yang digunakan rasa yang dihasilkan semakin manis khas ubi jalar ungu. Tetapi jika dilihat dari hasil penilaian panelis agak terlatih lebih menyukai sampel roti 
tawar subtitusi tepung ubi jalar ungu sebanyak $10 \%$ karena rasa manis yang dihasilkan lebih seimbang dibandingkan dengan sampel roti tawar yang lain.

\section{Kualitas Aroma}

Dari hasil penilaian yang dilakukan oleh 25 penelis agak terlatih mununjukkan sampel roti tawar subtitusi tepung ubi jalar ungu sebanyak 30\% merupakan sampel terbaik yaitu dengan kriteria beraroma khas ubi jalar ungu. Sedangkan sampel roti tawar subtitusi tepung ubi jalar ungu sebanyak $10 \%$ merupakan sampel yang kurang baik dengan kriteria aroma kurang khas ubi jalar ungu.

Penggunaan tepung ubi jalar ungu dan tepung terigu pada pembuatan roti tawar ini berpengaruh terhadap aroma roti tawar yang dihasilkan. Karena perbedaan jumlah tepung ubi jalar ungu dan tepung terigu menyebabkan kandungan protein yang terdapat pada tepung terigu dan karbohidrat pada tepung ubi jalar ungu berbeda. Adanya perbedaan protein dan karbohidrat menyebabkan terjadinya reaksi maillard, pada saat adonan dioven menghasilkan senyawa-senyawa volatil, sehingga menghasilkan aroma yang khas pada roti tawar yang dihasilkan (Winarno, 2002). Maka semakin banyak penggunaan tepung ubi jalar ungu, aroma yang dihasilkan lebih khas ubi jalar ungu dibandingkan dengan roti tawar yang tidak disubstitusi dengan tepung ubi jalar ungu.

\section{Kualitas Tekstur}

Hasil analisis yang dilakukan oleh 25 orang panelis menunjukkan bahwa perbeadaan prosentase tepung ubi jalar ungu dan tepung terigu pada pembuatan roti tawar berpengaruh terhadap tekstur pada roti tawar yang dihasilkan. Sampel roti tawar subtitusi tepung ubi jalar ungu sebanyak 30\% kurang disukai oleh panelis karena teksturnya berpori lembut dan padat atau kurang ringan. Berbeda dengan sampel roti tawar subtitusi tepung ubi jalar ungu sebanyak 10\% lebih banyak disukai oleh panelis karena teksturnya berpori lembut dan tidak padat serta dari penampilan sampel roti tawar mengembang tinggi dibanding dengan sampel roti tawar yang lain.

Perbedaan prosentase penggunaan tepung ubi jalar ungu dan tepung terigu menyebabkan kandungan protein, karbohidrat, lemak dan kandungan air pada tiap sampel berbeda. Dalam pembentukan tekstur dipengaruhi oleh protein, kandungan air, karbohidrat, lemak, suhu dan lama pemasakan. Menurut Nunung (2005), selama pengovenan terjadi peningkatan suhu dan tekanan uap air sehingga gelembung-gelembung udara pecah dan meninggalkan pori-pori pada roti tawar. Tekstur pada roti tawar subtitusi tepung ubi jalar ungu sebanyak $30 \%$ berpori lembut dan kurang mengembang tinggi, sedangkan tekstur roti tawar substitusi tepung terigu ubi jalar ungu sebanyak $10 \%$ dapat mengembang tinggi dan pori-porinya kurang lembut.

Hal ini dikarenakan pada tepung terigu mengandung protein yang tinggi dibanding dengan tepung ubi jalar ungu $(9: 2,79)$. Protein (gluten) pada tepung terigu berfungsi sebagai pembentuk struktur roti dan pengikat bahan yang lain. Maka semakin banyak tepung terigu yang digunakan semakin tinggi volume roti tawar (Sangkan Paran, 2009).

\section{Uji Laboratorium}

Berdasarkan data hasil uji laboratorium diperoleh sampel roti tawar dengan kandungan zat anthosianin dan serat kasar tertinggi adalah roti tawar subtitusi tepung ubi jalar ungu sebanyak $30 \%$ mengandung zat anthosianin $235,89 \mathrm{mg}$ dan serat kasar 2,34\%. Sampel roti tawar subtitusi tepung ubi jalar ungu $20 \%$ mengandung zat anthosianin $150,47 \mathrm{mg}$ dan serat kasar 1,975. Sampel roti tawar subtitusi tepung ubi jalar ungu $10 \%$ mengandung zat anthosianin $76,34 \mathrm{mg}$ dan serat kasar $1,25 \%$. Adanya perbedaan jumlah zat anthosianin dan serat kasar pada masing-masing sampel dikeranakan perbeadaan jumlah tepung ubi jalar ungu yang digunakan dalam pembuatan roti tawar, semakin banyak tepung ubi jalar ungu yang digunakan maka semakin tinggi kandungan zat anthosianin dan serat kasarnya.

Adanya kandungan zat anthosianin pada roti tawar dengan subtitusi tepung ubi jalar ungu mampu membantu memenuhi kebutuhan zat anthosianin (zat anti kanker) yang dapat berfungsi sebagai pencegah penyakin kanker, sedangkan kandungan serat pada roti tawar dengan subtitusi tepung ubi jalar ungu mampu memenuhi kebutuhan serat yang berfungsi untuk memperlancar buang air besar dan mencegah sembelit.

\section{Uji Kesukaan}


Berdasarkan hasil uji kesukaan pada sampel roti tawar yang paling disukai oleh seluruh responden adalah sampel roti tawar dengan subtitusi tepung ubi jalar ungu sebesar 10\% yang menghasilkan kriteria warna coklat keputihan, rasa tawar khas ubi jalar ungu, aroma kurang khas ubi jalar ungu dan tekstur berpori lembut dan tidak padat atau ringan dibandingkan dengan sampel roti tawar subtitusi ubi jalar ungu yang berprosentase $20 \%$ dan $30 \%$.

\section{Daya Simpan}

Daya simpan roti tawar subtitusi tepung ubi jalar ungu ini hanya dapat bertahan sampai 3 hari dari pada roti tawar murni tepung terigu. Hal itu disebabkan karena kandungan kadar air pada tepung ubi ungu lebih tinggi dari pada tepung terigu yaitu 15\% untuk tepung ubi jalar ungu dan 10\% - 14\% untuk tepung terigu. Dengan kandungan air yang lebih tinggi itu sangat mempengaruhi tekstur dan daya simpan roti tawar.

Semakin banyak tepung ubi jalar ungu yang dipergunakan maka daya simpan atau keawetan dari roti tawar semakin berkurang. Dari 3 sampel yang telah dibuat, daya simpan yang lebih tahan lama dalam 3 hari adalah sampel roti tawar subtitusi ubi ungu sebesar $10 \%$.

\section{KESIMPULAN}

Semakin banyak prosentasi pemberian tepung ubi jalar ungu pada pembuatan roti tawar maka akan mempengaruhi kualitas hasil roti tawar yang ditinjau dari aspek warna (dalam dan luar), aroma, rasa dan tekstur roti tawar serta kandungan zat athosianin dan serat lebih tinggi. Akan tetapi masyarakar lebih suka dengan roti tawar subtitusi tepung ubi jalar ungu dengan prosentase yang paling sedikit.

\section{UCAPAN TERIMA KASIH}

Ucapan Terimakasih saya berikan kepada Dra. Rosidah, M.Si dan Dra. Titin Agustina, M.Kes selaku dosen yang telah membimbing. Terima kasih juga saya ucapkan kepada teman-teman yang telah membantu dalam uji coba produk dan yang telah bersedia membantu dalam penelitian.

\section{REFERENSI}

Astawan, M. dan S. Widowati. 2005. Evaluasi Mutu Gizi dan Indeks Glikemik Ubi Jalar sebagai Dasar Pengembangan Pangan Fungsional. Laporan Hasil Penelitian Rusnas Diversifikasi Pangan Pokok. Institut Pertanian Bogor. Bogor. 7(2): 57-66.

Bayu, I.G.P. 2008. Analisa Financial dan Strategi Pengembangan Usaha Pengolahan Tepung Ikan Lemuru (Sardinella Lemuru) Di PT. Indo Bali, Jembrana. Jakarta: Sekolah Tinggi Perikanan

El Hida, Ramdhania. 2013. Selain Daging, Ini Bahan Pangan yang Dibeli RI dari Luar Negeri. Diakses dari http://finance.detik.com/read/ pada 28 Desember 2014.

Jawi, I. M. dan K. Budiasa. 2011. Ekstrak air umbi ubi jalar ungu menurunkan total kolesterol serta meningkatkan total antioksidan darah kelinci. Jurnal Veteriner. 12(2):120-125.

Katsube, T., N. Imawaka, Y. Kawano, Y. Yamazaki, K. Shiwaku and Y. Yamane, 2003. Antioxidant flavonol glycosides in mulberry (Morus alba L.) leaves isolated based on LDL antioxidant activity. Food Chemistry, 97: 25-31.

Kumalaningsih, S. 2006. Antioksidan Alami. Trubus Agrisarana. Surabaya. $112 \mathrm{hlm}$.

Mantred Lange dan Bogasari Baking Center. 2006. Roti Teori dan Resep Internasional. Jakarta : PT. Gratika Sarwono, B. 2005. Ubi Jalar Cara Budi Daya yang Tepat Efisien dan Ekonomis Seni Agribisnis. Jakarta : Sluaelaya

Sriboga Ratu Raya. 2005. Sekilas tentang Tepung Terigu dengan Aplikasinya : Semarang

Terahara, N., T. Honda, M. Hayashi, dan K. Ishimaru . 2004. New anthocyanins from purple pods of pea (Pisumspp.). Journal Bioscience, Biotechnol, Biochem, 64 (12) : 2569-2574.

Winarno, F.G.1997. Kimia Pangan dan Gizi. Jakarta : Gramedia Pustaka utama www.bogasariflour.com browsing on 28 Desember 2010 Multi warna

Mudjajanto, SetyonE dan Yulianti, L. N. 2004. Membuat Aneka Roti. Jakarta : Penebar Swadaya

Nunung. 2009. Rahasia Antigagal Membuat Aneka Kue Populer. Jakarta : Demedia

Paran, Sangkan. 2009. 100+ Tips Antigagal Bikin Roti, Cake, Pastry, dan Kue Kering. Jakarta : Kawan Pustaka 
Santoso, W. E. A. dan T. Estiasih. 2014. Kopigmentasi ubi jalar ungu (Ipomoea Batatas var. Ayamurasaki) dengan kopigmen na-kaseinat dan protein whey serta stabilitasnya terhadap pemanasan. Fakultas Teknologi Pertanian Universitas Brawijaya, Malang. Jurnal Pangan dan Agroindustri, 2: 121-127. 